\title{
EVALUASI KEBUTUHAN ANGKUTAN UMUM PENUMPANG KOTA MALANG (STUDI KASUS RUTE ARJOSARI-DINOYO-LANDUNGSARI)
}

\section{Evaluation The Needs of Public Transport Passengers in Malang Town (Case Studies Route Arjosari-Dinoyo-Landungsari)}

\author{
Khoirul Abadi ${ }^{1}$, Ruskandi ${ }^{2}$ \\ ${ }^{1}$ Jurusan Teknik Sipil Fakultas Teknik Universitas Muhammadiyah Malang \\ ${ }^{2}$ Dosen Teknik Sipil Universitas Muhammadiyah Malang \\ Kampus III Jalan Raya Tlogomas No. 246 Telp (0341) 464318 psw 176 Malang 65144 \\ Email: Ruskandi73@yahoo.com
}

\begin{abstract}
Public transport passengers in Malang called angkot is one of the means of transportation that allows people to perform daily activities, but transport is increasingly interested in the community due to the low level of services, so that many people to using private vehicles. The fleet of public transport passengers (FPTP) routes ADL is currently 118 units with a capacity of 12 passenger/vehicle. Purpose of this study is to determine the performance, productivity and the needs of FPTP ADL optimal trajectory in the city of Malang. The method used in this study adopts the Technical Guidelines for the Implementation of Public Transport in Cities in Fixed Route and Regular (Direktorat Jendral Perhubungan Darat 2002) and using empirical formulations. The study of public transport performance passenger route ADL in 2015, the average load factor of $97.06 \%$, the average frequency of 23.56 vehicle/hour, average headway time of 2.60 minutes, the average travel time $4,10 \mathrm{~min} / \mathrm{km}$, average travel speed of $15.03 \mathrm{~km} / \mathrm{hour}$. The average productivity of 55 passenger/day-vehicle with optimal fleet size is 116 units.
\end{abstract}

Keywords: Public Transport, Performance, Productivity

\begin{abstract}
Abstrak
Angkutan umum penumpang di Kota Malang disebut angkot adalah salah satu sarana transportasi yang digunakan masyarakat untuk melakukan aktifitas sehari-hari, namun angkutan ini semakin tidak diminati masyarakat akibat rendahnya tingkat pelayanan, sehingga masyarakat banyak menggunakan kendaraan pribadi. Armada angkutan umum penumpang (AUP) trayek ADL saat ini 118 unit dengan kapasitas 12 pnp/kend. Tujuan studi ini untuk mengetahui kinerja, produktivitas dan jumlah armada AUP trayek ADL yang optimal di kota Malang. Metode yang digunakan dalam studi ini mengadopsi dari Pedoman Teknis Penyelenggaraan Angkutan Penumpang Umum di Wilayah Perkotaan dalam Trayek Tetap dan Teratur (Direktorat Jendral Perhubungan Darat 2002) dan menggunakan formulasi empiris. Hasil studi kinerja angkutan umum penumpang trayek ADL tahun 2015, load factor rata-rata 97,06 \%, frekuensi rata-rata 23,56 kend/jam, headway waktu rata-rata 2,60 menit, waktu tempuh rata-rata 4,10 menit/km, kecepatan tempuh rata-rata $15,03 \mathrm{~km} / \mathrm{jam}$. Produktivitas rata-rata $55 \mathrm{pnp} /$ hari-kend, dengan jumlah armada yang optimal yaitu 116 unit.
\end{abstract}

Kata Kunci : Angkutan Umum, Kinerja, Produktivitas

\section{PENDAHULUAN}

Kota Malang merupakan kota terbesar kedua di Jawa Timur setelah Surabaya dan salah satu kota yang memiliki posisi sangat strategis secara geografis, selain itu Kota Malang terkenal dengan semboyan Tri Bina Citra yaitu sebagai Kota Pendidikan, Kota Industri dan Kota Pariwisata yang mencerminkan profil potensi ekonomi Kota Malang. Padatnya kegiatan berbanding lurus dengan berkembangnya pergerakan masyarakat yang menuntut kebutuhan transportasi yang lebih berkembang. Perkembangan tersebut menghadapkan Kota Malang pada keseimbangan antara supply dan demand, meningkatnya jumlah pengguna 
kendaraan pribadi akibat rendahnya tingkat pelayanan dan kinerja angkutan umum.

Angkutan umum penumpang di Kota Malang biasa dikenal dengan sebutan angkot adalah salah satu sarana transportasi yang digunakan untuk melayani aktivitas masyarakat di kota Malang. Terdapat sekitar 25 jalur angkutan umum penumpang di Kota Malang salah satunya adalah angkutan umum penumpang trayek ADL dengan panjang rute yaitu $\pm 14,5 \mathrm{~km}$ dan waktu tempuh \pm 1 jam . Menurut data Dinas Perhubungan Kota Malang (2015) untuk trayek ADL berjumlah 118 unit dengan kapasitas 12 penumpang, tarif Rp. 3.500 untuk pelajar dan Rp. 4.000 untuk umum.

Tujuan studi ini untuk mengetahui kinerja, produktivitas dan kebutuhan angkutan umum penumpang rute Arjosari - Dinoyo Landungsari kondisi saat ini (2015). Adapun manfaat dari studi ini diharapkan dapat dijadikan sebagai bahan pertimbangan dan masukan bagi instansi terkait untuk memperbaiki pelayanan angkutan umum penumpang Kota Malang.

\section{Angkutan Umum Penumpang}

Angkutan umum penumpang adalah angkutan penumpang yang dilakukan dengan sistem bayar atau sewa. Termasuk dalam pengertian angkutan umum penumpang adalah angkutan kota (bus, minibus, mikrolet $\mathrm{dsb}$ ), kereta api, angkutan air dan angkutan udara (Warpani :1990).

Menurut (Warpani:1990), pengadaan pelayanan AUP memang secara langsung mengurangi banyaknya kendaraan pribadi, namun AUP bukan salah satu jalan keluar untuk menyelesaikan masalah lalu-lintas kota. Pelayanan AUP akan berjalan baik apabila tercipta keseimbangan antara penyediaan dan permintaan.

\section{Kinerja Angkutan}

Indikator kualitas pelayanan operasi angkutan dapat dilihat dari nilai kinerja operasi yang dihasilkan, parameter yang digunakan frekuensi, headway, load factor, kecepatan perjalanan dan waktu tempuh Asikin (2001).

Frekuensi adalah jumlah kendaraan yang lewat per satuan waktu Morlok (1978). Frekuensi dapat dirumuskan sebagai berikut :

$$
\begin{aligned}
\mathrm{F} & =1 / \mathrm{h} \\
\text { Dimana }: \mathrm{F} & =\text { frekuensi } \\
\mathrm{h} & =\text { headway (menit) }
\end{aligned}
$$

Headway adalah waktu antara satu kendaraan dengan kendaraan lain yang berurutan dibelakangny pada satu rute yang sama Asikin (2001). Nilai headway dirumuskan sebagai berikut :

Dimana:

$$
\mathrm{Ht}=\frac{60}{\mathrm{Q} / \mathrm{jam}}
$$

$\mathrm{Q} / \mathrm{jam}=$ jumlah kendaraan per satuan jam
$\mathrm{Ht} \quad=$ headway (menit)

Load factor (LF) merupakan perbandingan antara kapasitas terjual dan kapasitas tersedia untuk satu perjalanan yang biasa dinyatakan dalam persen (\%) (Abubakar,1995).

$$
\mathrm{LF}=\frac{\mathrm{JF}}{\mathrm{C}} \times 100 \%
$$

Dimana :

$$
\begin{aligned}
& \mathrm{LF}=\text { Load Factor }(\%) \\
& \mathrm{JF}=\text { Banyaknya penumpang yang } \\
& \text { diangkut sepanjang satu lintasan pertrip. } \\
& \mathrm{C}=\text { kapasitas kendaraan. }
\end{aligned}
$$

Menurut Direktorat Jendral Perhubungan Darat (1995), bahwa nilai load factor dalam kondisi dinamis $70 \%$.

Menurut Morlok (1978) menyatakan bahwa kecepatan perjalanan yaitu kecepatan kendaraan dari awal rute ke titik akhir rute, dan dirumuskan dengan :

$$
\mathrm{V}=\mathrm{S} / \mathrm{t}
$$

\section{Dimana :}

$$
\begin{aligned}
& \mathrm{V}=\begin{array}{l}
\text { Kecepatan tempuh angkutan umum } \\
(\mathrm{Km} / \mathrm{jam})
\end{array} \\
& \begin{aligned}
\mathrm{S}= & \text { Jarak Tempuh Angkutan Umum }(\mathrm{Km}) \\
\mathrm{t} & =\underset{(\mathrm{Jam})}{\text { Waktu Tempuh Angkutan Umum }}
\end{aligned}
\end{aligned}
$$

\section{Produktivitas Angkutan}

Dalam indikator produktivitas parameter yang digunakan adalah total produksi kendaraan. pengertian total produksi kendaraan adalah rata-rata pencapaian jumlah penumpang yang dapat diangkut dalam satu hari dan satu kendaraan. Produktivitas dapat dirumuskan menggunakan formulasi empiris sebagai berikut :

Produktivitas $=$ jumlah penumpang rata - rata (pnp/trip-kend) $\mathrm{x}$ jumlah trip rata-rata (trip/hari) 


\section{Kebutuhan Angkutan}

Menggunakan formulasi empiris dengan mempertimbangkan produktivitas angkutan

\section{Kebutuhan Armada}

$=\frac{\text { Jumlah pnumpang/hari }}{\text { Produktivitas angkutan }}$ http://ejournal.umm.ac.id/index.php/jmts/article/view/3318

\section{METODE PENELITIAN}

\section{Lokasi Studi dan Pembagian Zona}

Angkutan umum penumpang trayek ADL memiliki panjang rute pergi-pulang $\pm 14,5$ $\mathrm{km}$.

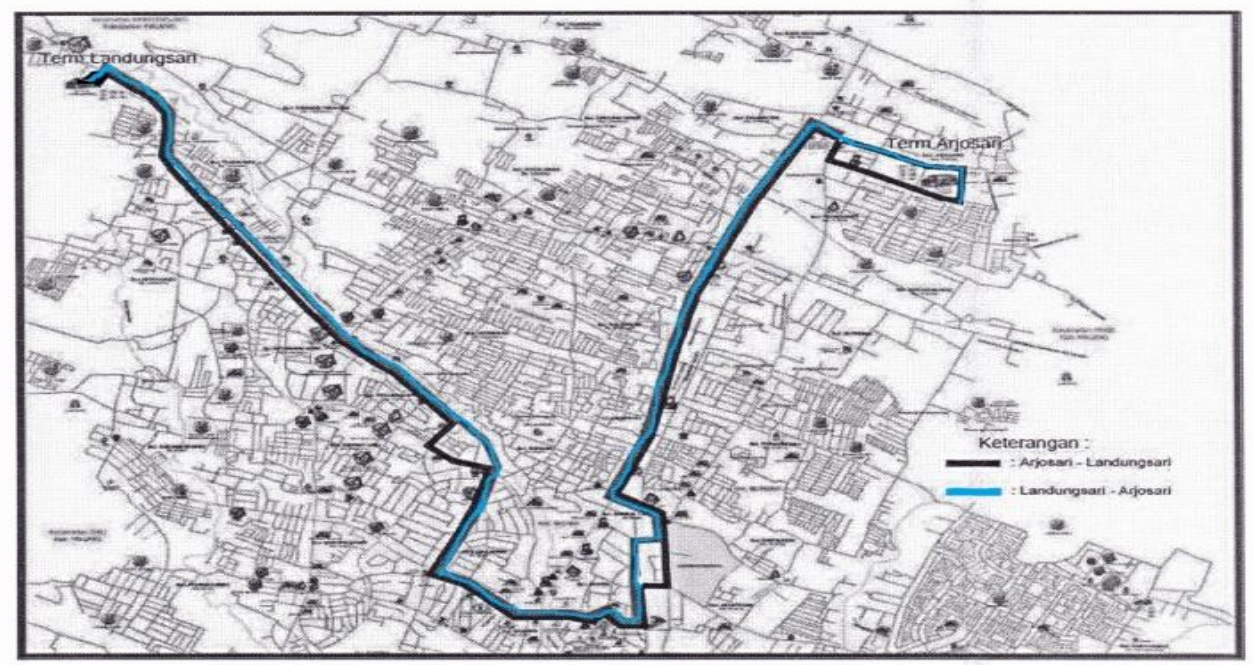

Gambar 1. Peta Angkutan Umum Penumpang Trayek ADL

Tabel 1. Pembagian Zona AUP trayek ADL arah Arjosari - Dinoyo - Landungsari

\begin{tabular}{cl}
\hline Zona & \multicolumn{1}{c}{ Lokasi Pengamatan } \\
\hline 1 & Terminal Arjosari - Jl.Jend.A.yani(Mesjid Sabilillah) \\
2 & Mesjid Sabilillah (Jl. Jend. A. Yani) - Hotel Ibis Style (Jl. Letjen S. Parman) \\
3 & Hotel Ibis Style (Jl. Letjen S. Parman) - Hotel Savana (Jl. Letjen Sutoyo) \\
4 & Hotel Savana (Jl. Letjen Sutoyo) - Stasiun KA Kota Baru \\
5 & Stasiun KA Kota Baru- Bank. BCA (Jl. Kahuripan) \\
6 & Bank BCA(Jl. Kahuripan) - Museum Brawijaya \\
7 & Museum Brawijaya - Taman Makam Pahlawan (Jl. Bandung - Jl. Bogor) \\
8 & Taman Makam Pahlawan (Jl. Bogor) - Kampus. UB (Jl.Mayjen Haryono) \\
9 & Kampus.UB (Jl. Mayjen Haryono) - Kampus UNISMA (Jl. Mt.Haryono) \\
10 & Kampus UNISMA (Jl.Mt.Haryono) - Terminal Landungsari \\
\hline
\end{tabular}

Tabel 2. Pembagian Zona AUP trayek ADL arah Landungsari - Dinoyo - Landungsari.

\begin{tabular}{cl}
\hline Zona & \multicolumn{1}{c}{ Lokasi Pengamatan } \\
\hline 11 & Terminal Landungsari - Kampus UNISMA (Jl. Mt.Haryono) \\
12 & Kampus UNISMA( Jl. Mt.Haryono) - Kampus UB (Jl. Mayjen Haryono) \\
13 & Kampus UB (Jl. Mayjen Haryono) - kampus Pariwisata Unmer (Jl. Ijen) \\
14 & Kampus Pariwisata Unmer (Jl. Ijen) - Perpustakaan Kota (Jl. Ijen) \\
15 & Perpustakaan Kota (Jl. Ijen) - Bank BCA (Jl. Kahuripan) \\
16 & Bank BCA(Jl. Kahuripan) - Stasiun KA Kota Baru (Jl. Kertanegara) \\
17 & Stasiun KA Kota Baru (Jl. Kertanegara) - Hotel Savana Jl. Letjen Sutoyo) \\
18 & Hotel Savana Jl. Letjen Sutoyo) - Hotel Ibis Style (Jl. Letjen S. Parman) \\
19 & Hotel Ibis Style (Jl. Letjen S. Parman) - Mesjid Sabilillah (jl. Jend A Yani) \\
20 & Mesjid Sabilillah (jl. Jend A Yani) - Terminal Arjosari \\
\hline
\end{tabular}




\section{Tahapan Studi}

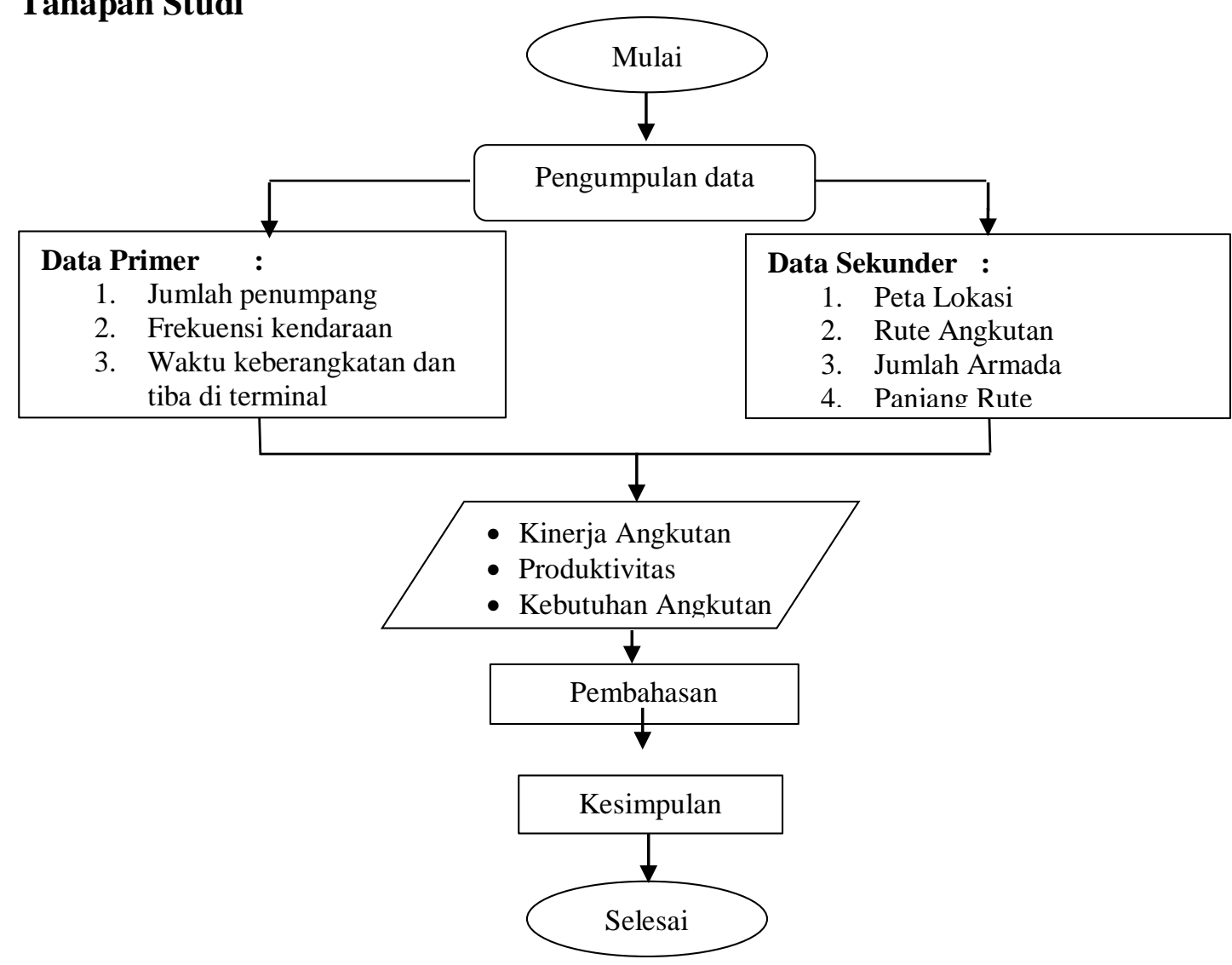

Gambar 2. Bagan Alur Studi

\section{HASIL DAN PEMBAHASAN}

\section{Data Penumpang}

Hasil survey untuk penumpang dilakukan mulai pukul 06.00-18.00 WIB, disajikan pada tabel 3 .

Tabel 3. Penumpang AUP trayek ADL

\begin{tabular}{|c|c|c|c|c|c|c|c|c|c|c|c|c|c|c|c|c|c|c|c|c|c|c|c|c|}
\hline \multirow{3}{*}{$\begin{array}{c}\text { Jam } \\
\text { Berang- } \\
\text { kat }\end{array}$} & \multicolumn{12}{|c|}{ Arjosari - Dinoyo - Landungsari } & \multicolumn{12}{|c|}{ Landungsari - Dinoyo - Arjosari } \\
\hline & \multicolumn{2}{|c|}{ Sabtu } & \multicolumn{2}{|c|}{ Minggu } & \multicolumn{2}{|c|}{ Senin } & \multicolumn{2}{|c|}{ Selasa } & \multicolumn{2}{|c|}{ Rabu } & \multicolumn{2}{|c|}{ Kamis } & \multicolumn{2}{|c|}{ Sabtu } & \multicolumn{2}{|c|}{ Minggu } & \multicolumn{2}{|c|}{ Senin } & \multicolumn{2}{|c|}{ Selasa } & \multicolumn{2}{|c|}{ Rabu } & \multicolumn{2}{|c|}{ Kamis } \\
\hline & $\mathrm{U}$ & $\mathrm{P}$ & $\mathrm{U}$ & $\mathrm{P}$ & $\mathrm{U}$ & $\mathrm{P}$ & $\mathrm{U}$ & $\mathrm{P}$ & $\mathrm{U}$ & $\mathrm{P}$ & $\mathrm{U}$ & $\mathrm{P}$ & $\mathrm{U}$ & $\mathrm{P}$ & $\mathrm{U}$ & $\mathrm{P}$ & $\mathrm{U}$ & $\mathrm{P}$ & $\mathrm{U}$ & $\mathrm{P}$ & $\mathrm{U}$ & $\mathrm{P}$ & $\mathrm{U}$ & $\mathrm{P}$ \\
\hline $6: 00$ & 8 & 1 & 12 & 0 & 7 & 2 & 8 & 0 & 6 & 1 & 8 & 1 & 7 & 1 & 7 & 0 & 5 & 2 & 6 & 1 & 8 & 1 & 4 & 4 \\
\hline $6: 30$ & 10 & 0 & 10 & 0 & 10 & 1 & 7 & 0 & 10 & 1 & 13 & 2 & 6 & 2 & 11 & 0 & 7 & 2 & 7 & 1 & 8 & 0 & 9 & 1 \\
\hline 7:00 & 6 & 1 & 14 & 0 & 12 & 1 & 12 & 1 & 13 & 0 & 11 & 0 & 6 & 1 & 18 & 0 & 9 & 0 & 10 & 1 & 11 & 1 & 7 & 0 \\
\hline 8:00 & 12 & 0 & 7 & 0 & 16 & 0 & 17 & 1 & 11 & 0 & 13 & 0 & 13 & 0 & 10 & 0 & 8 & 0 & 12 & 0 & 10 & 0 & 9 & 0 \\
\hline 9:00 & 10 & 0 & 13 & 0 & 10 & 0 & 11 & 0 & 11 & 1 & 14 & 0 & 8 & 2 & 12 & 0 & 11 & 1 & 10 & 0 & 14 & 0 & 9 & 5 \\
\hline 10:00 & 15 & 3 & 15 & 0 & 15 & 1 & 8 & 3 & 15 & 3 & 12 & 6 & 14 & 4 & 13 & 0 & 10 & 4 & 10 & 0 & 15 & 1 & 5 & 3 \\
\hline $11: 00$ & 12 & 0 & 15 & 0 & 9 & 0 & 13 & 5 & 13 & 0 & 10 & 1 & 14 & 0 & 8 & 0 & 14 & 3 & 9 & 5 & 15 & 0 & 2 & 4 \\
\hline $12: 00$ & 13 & 6 & 14 & 0 & 11 & 0 & 14 & 0 & 11 & 0 & 12 & 0 & 13 & 0 & 9 & 0 & 11 & 2 & 19 & 0 & 12 & 1 & 6 & 3 \\
\hline $13: 00$ & 15 & 0 & 9 & 0 & 18 & 0 & 7 & 2 & 12 & 3 & 7 & 3 & 10 & 0 & 17 & 0 & 8 & 0 & 15 & 0 & 11 & 0 & 7 & 0 \\
\hline $13: 30$ & 11 & 0 & 18 & 0 & 5 & 2 & 15 & 0 & 12 & 0 & 11 & 0 & 12 & 0 & 10 & 0 & 10 & 0 & 11 & 4 & 8 & 0 & 12 & 0 \\
\hline $14: 00$ & 13 & 0 & 15 & 0 & 15 & 0 & 10 & 3 & 16 & 1 & 14 & 1 & 11 & 0 & 11 & 0 & 11 & 0 & 11 & 0 & 10 & 0 & 11 & 0 \\
\hline $15: 00$ & 18 & 0 & 10 & 0 & 11 & 0 & 17 & 1 & 18 & 0 & 14 & 0 & 12 & 1 & 8 & 0 & 11 & 2 & 16 & 1 & 11 & 1 & 12 & 1 \\
\hline $16: 00$ & 10 & 0 & 10 & 0 & 10 & 3 & 10 & 1 & 12 & 0 & 11 & 3 & 15 & 0 & 10 & 0 & 9 & 0 & 7 & 1 & 8 & 0 & 17 & 1 \\
\hline $16: 30$ & 11 & 0 & 11 & 0 & 7 & 2 & 9 & 0 & 8 & 1 & 11 & 0 & 10 & 0 & 13 & 0 & 9 & 0 & 13 & 0 & 13 & 0 & 10 & 0 \\
\hline $17: 00$ & 11 & 0 & 8 & 0 & 8 & 0 & 9 & 1 & 11 & 0 & 9 & 0 & 8 & 0 & 7 & 0 & 10 & 0 & 15 & 0 & 13 & 0 & 8 & 0 \\
\hline $17: 30$ & 9 & 0 & 8 & 0 & 9 & 0 & 7 & 0 & 10 & 0 & 10 & 0 & 8 & 0 & 9 & 0 & 13 & 0 & 8 & 0 & 11 & 0 & 9 & 0 \\
\hline
\end{tabular}

Sumber : Hasil Survey

Keterangan $n: U=$ Umum, $P=$ Pelajar 


\section{Waktu Tempuh}

Waktu tempuh angkutan umum penumpang trayek ADL disajikan pada tabel 4 . http://ejournal.umm.ac.id/index.php/jmts/article/view/3318

\section{Pola Naik Turun Penumpang}

Contoh kondisi eksisting pola naik turun penumpang maksimum AUP trayek ADL pada hari kamis, disajikan pada tabel 5 .

Tabel 4. Waktu Tempuh AUP trayek ADL (menit).

\begin{tabular}{|c|c|c|c|c|c|c|c|c|c|c|c|c|}
\hline \multirow{2}{*}{$\begin{array}{c}\text { Jam } \\
\text { Berangkat }\end{array}$} & \multicolumn{6}{|c|}{ Arjosari - Dinoyo - Landungsari } & \multicolumn{6}{|c|}{ Arjosari - Dinoyo - Landungsari } \\
\hline & Sabtu & Minggu & Senin & Selasa & Rabu & Kamis & Sabtu & Minggu & Senin & Selasa & Rabu & Kamis \\
\hline $6: 00$ & 57 & 54 & 56 & 53 & 58 & 64 & 52 & 38 & 55 & 53 & 55 & 53 \\
\hline $6: 30$ & 58 & 61 & 57 & 54 & 61 & 66 & 56 & 42 & 58 & 58 & 56 & 55 \\
\hline 7:00 & 56 & 53 & 66 & 59 & 60 & 59 & 51 & 50 & 56 & 60 & 58 & 56 \\
\hline $8: 00$ & 59 & 53 & 64 & 64 & 58 & 63 & 55 & 48 & 58 & 55 & 54 & 48 \\
\hline 9:00 & 55 & 57 & 55 & 64 & 61 & 61 & 50 & 57 & 58 & 53 & 53 & 48 \\
\hline $10: 00$ & 80 & 48 & 70 & 62 & 68 & 69 & 57 & 55 & 60 & 56 & 60 & 54 \\
\hline $11: 00$ & 53 & 68 & 55 & 57 & 60 & 55 & 54 & 53 & 55 & 46 & 57 & 50 \\
\hline $12: 00$ & 90 & 53 & 53 & 62 & 59 & 52 & 55 & 60 & 56 & 57 & 53 & 46 \\
\hline $13: 00$ & 65 & 59 & 57 & 61 & 64 & 61 & 60 & 55 & 58 & 56 & 55 & 47 \\
\hline $13: 30$ & 61 & 55 & 58 & 50 & 62 & 68 & 59 & 56 & 60 & 56 & 59 & 46 \\
\hline $14: 00$ & 52 & 60 & 59 & 58 & 61 & 56 & 54 & 55 & 57 & 48 & 62 & 50 \\
\hline $15: 00$ & 64 & 58 & 59 & 96 & 56 & 50 & 53 & 54 & 56 & 106 & 53 & 52 \\
\hline $16: 00$ & 63 & 61 & 57 & 100 & 61 & 52 & 57 & 59 & 67 & 101 & 56 & 56 \\
\hline $16: 30$ & 62 & 59 & 60 & 99 & 59 & 58 & 58 & 61 & 62 & 104 & 55 & 58 \\
\hline $17: 00$ & 58 & 53 & 59 & 98 & 56 & 58 & 54 & 52 & 56 & 100 & 59 & 42 \\
\hline $17: 30$ & 54 & 64 & 58 & 95 & 62 & 79 & 60 & 52 & 58 & 101 & 52 & 60 \\
\hline
\end{tabular}

Sumber : Hasil Survey

Tabel 5. Pola Naik Turun AUP maksimum trayek ADL.

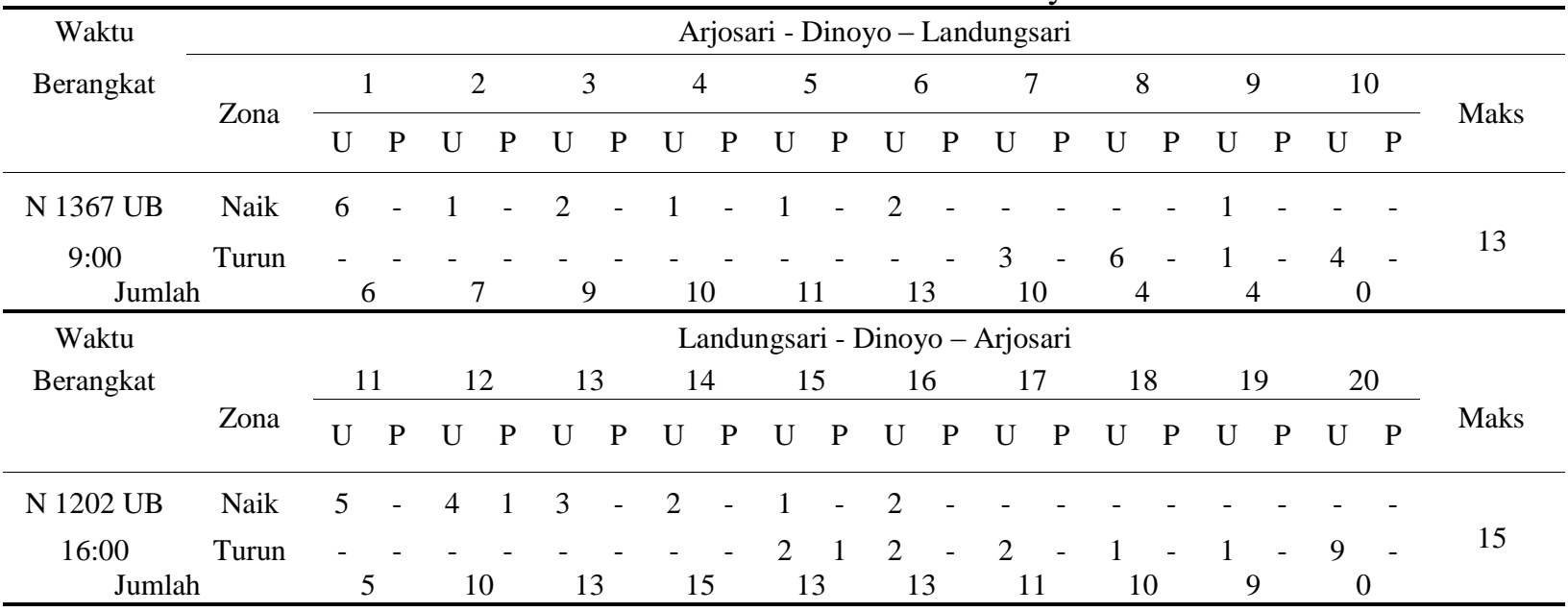

Sumber : Hasil Survey Kamis 11 Juni 2015

\section{Kendaraan}

Jumlah kendaraan angkutan umum penumpang trayek ADL yang terdaftar 118 unit, sedangkan jumlah kendaraan yang tercatat atau melewati lokasi titik pengamatan di jl. Trunojoyo disajikan pada tabel 6 . 
Tabel 6. Jumlah Kendaraan AUP trayek ADL (kend/15 menit)

\begin{tabular}{|c|c|c|c|c|c|c|c|c|c|c|c|c|}
\hline \multirow{2}{*}{$\begin{array}{c}\text { Arah } \\
\text { Hari } \\
\text { Jam }\end{array}$} & \multicolumn{6}{|c|}{ Arjosari - Dinoyo - Landungsari } & \multicolumn{6}{|c|}{ Landungsari - Dinoyo - Arjosari } \\
\hline & Sabtu & Minggu & Senin & Selasa & Rabu & Kamis & Sabtu & Minggu & Senin & Selasa & Rabu & Kamis \\
\hline $06.00-06.15$ & 5 & 7 & 7 & 6 & 7 & 6 & 4 & 5 & 5 & 3 & 4 & 4 \\
\hline $06.15-06.30$ & 5 & 4 & 8 & 8 & 6 & 5 & 5 & 5 & 4 & 5 & 4 & 3 \\
\hline $06.30-06.45$ & 5 & 5 & 5 & 5 & 6 & 7 & 6 & 5 & 4 & 4 & 5 & 5 \\
\hline $06.45-07.00$ & 6 & 6 & 7 & 9 & 8 & 7 & 4 & 4 & 5 & 4 & 5 & 4 \\
\hline $07.00-07.15$ & 10 & 5 & 6 & 9 & 6 & 8 & 4 & 4 & 7 & 4 & 6 & 5 \\
\hline $07.15-07.30$ & 7 & 6 & 7 & 6 & 7 & 6 & 6 & 5 & 6 & 7 & 4 & 5 \\
\hline $07.30-07.45$ & 7 & 6 & 5 & 4 & 5 & 9 & 8 & 5 & 5 & 6 & 7 & 6 \\
\hline $07.45-08.00$ & 6 & 7 & 8 & 6 & 5 & 8 & 7 & 5 & 6 & 4 & 5 & 6 \\
\hline $08.00-08.15$ & 7 & 8 & 5 & 4 & 4 & 7 & 8 & 6 & 7 & 6 & 6 & 5 \\
\hline $08.15-08.30$ & 11 & 7 & 9 & 9 & 7 & 6 & 4 & 6 & 7 & 10 & 8 & 7 \\
\hline $08.30-08.45$ & 7 & 10 & 8 & 7 & 8 & 5 & 6 & 5 & 6 & 9 & 7 & 8 \\
\hline $08.45-09.00$ & 9 & 4 & 6 & 6 & 6 & 7 & 8 & 5 & 6 & 9 & 7 & 8 \\
\hline $09.00-09.15$ & 8 & 10 & 6 & 6 & 5 & 6 & 4 & 4 & 7 & 7 & 6 & 6 \\
\hline $09.15-09.30$ & 8 & 7 & 6 & 5 & 4 & 8 & 4 & 5 & 6 & 4 & 5 & 6 \\
\hline $09.30-09.45$ & 7 & 10 & 8 & 9 & 8 & 7 & 8 & 4 & 7 & 4 & 4 & 5 \\
\hline $09.45-10.00$ & 4 & 8 & 6 & 5 & 5 & 7 & 6 & 6 & 5 & 8 & 8 & 5 \\
\hline $10.00-10.15$ & 7 & 6 & 7 & 7 & 6 & 8 & 6 & 3 & 5 & 4 & 5 & 4 \\
\hline $10.15-10.30$ & 6 & 4 & 7 & 8 & 7 & 5 & 6 & 7 & 8 & 4 & 7 & 5 \\
\hline $10.30-10.45$ & 4 & 6 & 5 & 4 & 4 & 7 & 4 & 10 & 7 & 7 & 6 & 5 \\
\hline $10.45-11.00$ & 9 & 8 & 8 & 9 & 6 & 8 & 8 & 8 & 7 & 6 & 5 & 5 \\
\hline $11.00-11.15$ & 6 & 5 & 7 & 4 & 3 & 6 & 8 & 7 & 8 & 7 & 6 & 6 \\
\hline $11.15-11.30$ & 6 & 6 & 6 & 6 & 4 & 6 & 6 & 4 & 7 & 5 & 5 & 5 \\
\hline $11.30-11.45$ & 6 & 6 & 6 & 5 & 7 & 6 & 6 & 4 & 6 & 5 & 6 & 5 \\
\hline $11.45-12.00$ & 5 & 7 & 6 & 4 & 5 & 5 & 6 & 6 & 7 & 4 & 5 & 6 \\
\hline $12.00-12.15$ & 6 & 6 & 5 & 5 & 4 & 5 & 6 & 4 & 8 & 7 & 6 & 5 \\
\hline $12.15-12.30$ & 4 & 8 & 5 & 5 & 6 & 7 & 4 & 8 & 5 & 6 & 4 & 5 \\
\hline $12.30-12.45$ & 4 & 6 & 7 & 7 & 5 & 7 & 6 & 4 & 6 & 6 & 6 & 4 \\
\hline $12.45-13.00$ & 7 & 5 & 7 & 7 & 5 & 8 & 7 & 7 & 7 & 5 & 5 & 4 \\
\hline $13.00-13.15$ & 6 & 4 & 7 & 5 & 7 & 6 & 4 & 6 & 7 & 5 & 4 & 4 \\
\hline $13.15-13.30$ & 5 & 5 & 5 & 4 & 4 & 5 & 4 & 5 & 6 & 7 & 8 & 5 \\
\hline $13.30-13.45$ & 9 & 5 & 5 & 7 & 6 & 4 & 5 & 3 & 5 & 6 & 4 & 5 \\
\hline $13.45-14.00$ & 4 & 5 & 6 & 5 & 9 & 4 & 7 & 7 & 6 & 6 & 5 & 6 \\
\hline $14.00-14.15$ & 5 & 5 & 6 & 6 & 9 & 7 & 5 & 4 & 6 & 7 & 6 & 6 \\
\hline $14.15-14.30$ & 4 & 6 & 7 & 6 & 4 & 6 & 6 & 5 & 6 & 7 & 4 & 5 \\
\hline $14.30-14.45$ & 4 & 4 & 7 & 8 & 5 & 8 & 7 & 4 & 7 & 6 & 8 & 7 \\
\hline $14.45-15.00$ & 6 & 5 & 8 & 4 & 4 & 6 & 6 & 7 & 7 & 5 & 7 & 8 \\
\hline $15.00-15.15$ & 5 & 4 & 4 & 9 & 6 & 4 & 4 & 4 & 5 & 4 & 6 & 6 \\
\hline $15.15-15.30$ & 8 & 4 & 7 & 7 & 4 & 7 & 5 & 6 & 5 & 5 & 6 & 5 \\
\hline $15.30-15.45$ & 6 & 6 & 6 & 5 & 5 & 6 & 6 & 7 & 5 & 6 & 4 & 5 \\
\hline $15.45-16.00$ & 5 & 6 & 5 & 4 & 6 & 5 & 6 & 4 & 7 & 6 & 9 & 6 \\
\hline $16.00-16.15$ & 11 & 4 & 4 & 5 & 6 & 4 & 6 & 5 & 6 & 4 & 6 & 5 \\
\hline $16.15-16.30$ & 7 & 5 & 6 & 6 & 5 & 5 & 9 & 5 & 7 & 6 & 5 & 4 \\
\hline $16.30-16.45$ & 8 & 5 & 5 & 6 & 4 & 4 & 5 & 5 & 5 & 4 & 4 & 4 \\
\hline $16.45-17.00$ & 6 & 3 & 8 & 7 & 7 & 7 & 7 & 4 & 6 & 9 & 7 & 6 \\
\hline $17.00-17.15$ & 5 & 5 & 6 & 6 & 6 & 7 & 5 & 4 & 6 & 7 & 5 & 7 \\
\hline $17.15-17.30$ & 4 & 4 & 5 & 4 & 6 & 6 & 6 & 4 & 4 & 7 & 6 & 5 \\
\hline $17.30-17.45$ & 4 & 5 & 5 & 4 & 5 & 5 & 5 & 5 & 4 & 6 & 7 & 6 \\
\hline $17.45-18.00$ & 5 & 4 & 5 & 5 & 4 & 5 & 4 & 4 & 5 & 5 & 5 & 4 \\
\hline
\end{tabular}

Sumber : Hasil Survey

\section{Kinerja Angkutan Umum Penumpang Trayek ADL}

\section{Load Factor (faktor muat)}

Load factor angkutan umum penumpang trayek ADL dihitung dengan menggunakan persamaan 3 , berdasarkan data penumpang (tabel 3). Load factor angkutan umum penumpang trayek ADL selengkapnya disajikan pada tabel 7 dan gambar 3 . 
Tabel 7. Load Factor Maksimum, Minimum dan Rata-rata AUP trayek ADL (\%)

\begin{tabular}{|c|c|c|c|c|c|c|c|c|c|c|c|c|}
\hline & \multicolumn{6}{|c|}{ Arjosari - Dinoyo - Landungsari } & \multicolumn{6}{|c|}{ Landungsari - Dinoyo - Landungsari } \\
\hline & Sabtu & Minggu & Senin & Selasa & Rabu & Kamis & Jumat & Sabtu & Minggu & Senin & Selasa & Rabu \\
\hline Maks & 158,33 & 150,00 & 150,00 & 150,00 & 150,00 & 150,00 & 150,00 & 150,00 & 141,67 & 158,33 & 133,33 & 150,00 \\
\hline Min & 58,33 & 58,33 & 58,33 & 58,33 & 58,33 & 75,00 & 58,33 & 58,33 & 58,33 & 58,33 & 66,67 & 50,00 \\
\hline $\begin{array}{l}\text { Rata- } \\
\text { rata }\end{array}$ & 101,56 & 98,44 & 96,35 & 100,00 & 104,17 & 102,60 & 92,71 & 90,10 & 89,58 & 100,52 & 95,31 & 82,81 \\
\hline $\begin{array}{c}\text { Maks } \\
\text { Min }\end{array}$ & & & & & & & & & $\begin{array}{c}158 \\
50\end{array}$ & & & \\
\hline $\begin{array}{l}\text { Rata- } \\
\text { rata }\end{array}$ & & & & & & & & & 91 & & & \\
\hline $\begin{array}{l}\text { Maks } \\
\text { Min }\end{array}$ & & & & & & $\begin{array}{c}158 \\
50\end{array}$ & & & & & & \\
\hline $\begin{array}{c}\text { Rata- } \\
\text { rata }\end{array}$ & & & & & & 97 & & & & & & \\
\hline
\end{tabular}

Sumber : Hasil Perhitungan

\section{Frekuensi dan Headway}

Frekuensi dan headway angkutan umum penumpang trayek ADL dihitung menggunakan persamaan 1 dan persamaan 2, berdasarkan data frekuensi kendaraan (tabel

6), Frekuensi rata-rata dan headway waktu rata-rata angkutan umum penumpang trayek ADL selengkapnya disajikan pada tabel 8 dan tabel 9.

Tabel 8. Frekuensi Maksimum, Minimum dan Rata-Rata AUP trayek ADL (kend/jam)

\begin{tabular}{|c|c|c|c|c|c|c|c|c|c|c|c|c|}
\hline & \multicolumn{6}{|c|}{ Arjosari - Dinoyo - Landungsari } & \multicolumn{6}{|c|}{ Landungsari - Dinoyo - Arjosari } \\
\hline & Sabtu & Minggu & Senin & Selasa & Rabu & Kamis & Sabtu & Minggu & Senin & Selasa & Rabu & Kamis \\
\hline Maks & 35 & 35 & 30 & 31 & 28 & 31 & 29 & 32 & 30 & 35 & 28 & 29 \\
\hline Min & 17 & 17 & 20 & 19 & 17 & 18 & 19 & 17 & 18 & 18 & 18 & 17 \\
\hline $\begin{array}{c}\text { Rata- } \\
\text { rata }\end{array}$ & 25 & 23 & 25 & 24 & 23 & 25 & 24 & 21 & 24 & 24 & 23 & 22 \\
\hline Maks & & & 35 & & & & & & 35 & & & \\
\hline Min & & & 17 & & & & & & 17 & & & \\
\hline $\begin{array}{c}\text { Rata- } \\
\text { rata }\end{array}$ & & & 24.2 & & & & & & 22.88 & & & \\
\hline Maks & & & & & & 3 & & & & & & \\
\hline Min & & & & & & 1 & & & & & & \\
\hline $\begin{array}{c}\text { Rata- } \\
\text { rata }\end{array}$ & & & & & & 23 & & & & & & \\
\hline
\end{tabular}

Sumber : Hasil Perhitungan

Tabel 9. Headway Maksimum, Minimum dan Rata-Rata AUP trayek ADL(menit)

\begin{tabular}{|c|c|c|c|c|c|c|c|c|c|c|c|c|}
\hline & \multicolumn{6}{|c|}{ Arjosari - Dinoyo - Landungsari } & \multicolumn{6}{|c|}{ Landungsari - Dinoyo - Arjosari } \\
\hline & Sabtu & Minggu & Senin & Selasa & Rabu & Kamis & Sabtu & Minggu & Senin & Selasa & Rabu & Kamis \\
\hline Maks & 3.53 & 3.53 & 3.00 & 3.16 & 3.53 & 3.33 & 3.16 & 3.53 & 3.33 & 3.33 & 3.33 & 3.53 \\
\hline Min & 1.71 & 1.71 & 2.00 & 1.94 & 2.14 & 1.94 & 2.07 & 1.88 & 2.00 & 1.71 & 2.14 & 2.07 \\
\hline $\begin{array}{c}\text { Rata- } \\
\text { rata }\end{array}$ & 2.45 & 2.67 & 2.41 & 2.52 & 2.69 & 2.44 & 2.60 & 2.93 & 2.48 & 2.59 & 2.64 & 2.81 \\
\hline Maks & & & 3.53 & & & & & & 3.53 & & & \\
\hline Min & & & 1.71 & & & & & & 1.71 & & & \\
\hline $\begin{array}{c}\text { Rata- } \\
\text { rata }\end{array}$ & & & 2.53 & & & & & & 2.67 & & & \\
\hline Maks & & & & & & 3. & 53 & & & & & \\
\hline Min & & & & & & 1.' & 71 & & & & & \\
\hline $\begin{array}{c}\text { Rata- } \\
\text { rata }\end{array}$ & & & & & & 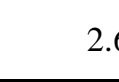 & 60 & & & & & \\
\hline
\end{tabular}

Sumber : Hasil Perhitungan 


\section{Waktu Tempuh}

Waktu tempuh maksimum, minimum dan rata-rata masing-masing angkutan umum penumpang berdasarkan data waktu tempuh (tabel 4), selengkapnya disajikan pada tabel 10.

Angkutan umum penumpang arah Arjosari - Dinoyo - Landungsari, waktu tempuh maksimum sebesar 6,90 menit $/ \mathrm{km}$ pada hari Selasa keberangkatan pukul 16.00. Sedangkan waktu tempuh minimum sebesar
3,31 menit/km pada hari Minggu keberangkatan pukul 10.00. Untuk arah Landungsari - Dinoyo Arjosari waktu tempuh maksimum sebesar 7,31 menit/km pada hari Selasa keberangkatan pukul 15.00. Sedangkan waktu tempuh minimum sebesar 2,60 menit/km pada hari Minggu keberangkatan pukul 06.00. Adapun waktu tempuh rata - rata kedua arah sebesar 4,10 menit $/ \mathrm{km}$.

Tabel 10. Waktu Tempuh Maksimum, Minimum dan Rata-Rata AUP trayek ADL (menit/km)

\begin{tabular}{|c|c|c|c|c|c|c|c|c|c|c|c|c|}
\hline & \multicolumn{6}{|c|}{ Arjosari - Dinoyo - Landungsari } & \multicolumn{6}{|c|}{ Arjosari - Dinoyo - Landungsari } \\
\hline & Sabtu & Minggu & Senin & Selasa & Rabu & Kamis & Sabtu & Minggu & Senin & Selasa & Rabu & Kamis \\
\hline maks & 6.21 & 4.69 & 4.83 & 6.90 & 4.69 & 5.45 & 4.14 & 4.21 & 4.62 & 7.31 & 4.28 & 4.14 \\
\hline Min & 3.59 & 3.31 & 3.66 & 3.45 & 3.86 & 3.45 & 3.45 & 2.62 & 3.79 & 3.17 & 3.59 & 2.90 \\
\hline $\begin{array}{c}\text { Rata- } \\
\text { rata }\end{array}$ & 4.25 & 3.95 & 4.06 & 4.88 & 4.16 & 4.19 & 3.81 & 3.65 & 4.01 & 4.78 & 3.87 & 3.54 \\
\hline maks & & & 6.90 & & & & & & 7.3 & & & \\
\hline Min & & & 3.31 & & & & & & 2.6 & & & \\
\hline $\begin{array}{c}\text { Rata- } \\
\text { rata }\end{array}$ & & & 4.25 & & & & & & 3.9 & & & \\
\hline maks & & & & & & 4.2 & & & & & & \\
\hline Min & & & & & & 2.6 & & & & & & \\
\hline $\begin{array}{c}\text { Rata- } \\
\text { rata }\end{array}$ & & & & & & 4.1 & & & & & & \\
\hline
\end{tabular}

Sumber : Hasil Perhitungan

\section{Kecepatan Tempuh}

Kecepatan tempuh angkutan umum penumpang trayek ADL dihitung menggunakan persamaan 4 , berdasarkan data waktu tempuh (tabel 4) dan jarak tempuh 14,5 $\mathrm{km}$. Kecepatan tempuh angkutan umum penumpang trayek ADL selengkapnya disajikan pada tabel 11 dan gambar 4 .

Tabel 11. Kecepatan Tempuh Maksimum, Minumum dan Rata-Rata AUP trayek ADL (km/jam)

\begin{tabular}{|c|c|c|c|c|c|c|c|c|c|c|c|c|}
\hline & \multicolumn{6}{|c|}{ Arjosari - Dinoyo - Landungsari } & \multicolumn{6}{|c|}{ Landungsari - Dinoyo - Arjosari } \\
\hline & Sabtu & Minggu & Senin & Selasa & Rabu & Kamis & Sabtu & Minggu & Senin & Selasa & Rabu & Kamis \\
\hline Maks & 16.7 & 18.1 & 16.4 & 17.4 & 15.5 & 17.4 & 17.4 & 22.9 & 15.8 & 18.9 & 16.7 & 20.7 \\
\hline Min & 9.7 & 12.8 & 12.4 & 8.7 & 12.8 & 11.0 & 14.5 & 14.3 & 13.0 & 8.2 & 14.0 & 14.5 \\
\hline $\begin{array}{c}\text { Rata- } \\
\text { rata }\end{array}$ & 14.4 & 15.3 & 14.8 & 13.1 & 14.4 & 14.5 & 15.8 & 16.7 & 15.0 & 13.7 & 15.6 & 17.1 \\
\hline Maks & \multicolumn{6}{|c|}{18.13} & \multicolumn{6}{|c|}{22.89} \\
\hline Min & \multicolumn{6}{|c|}{8.70} & \multicolumn{6}{|c|}{8.21} \\
\hline $\begin{array}{c}\text { Rata- } \\
\text { rata }\end{array}$ & \multicolumn{6}{|c|}{14.43} & \multicolumn{6}{|c|}{15.64} \\
\hline Maks & \multicolumn{12}{|c|}{22.89} \\
\hline Min & \multicolumn{12}{|c|}{8.21} \\
\hline $\begin{array}{c}\text { Rata- } \\
\text { rata }\end{array}$ & \multicolumn{12}{|c|}{15.03} \\
\hline
\end{tabular}

Sumber : Hasil Perhitungan 


\section{Produktivitas}

Berdasarkan jumlah kendaraan (tabel 6), dapat diketahui jumlah trip perhari, sebagaimana disajikan pada tabel 12 . Sedangkan berdasar data penumpang (tabel
3), dapat diketahui jumlah penumpang ratarata (Pnp/trip-kend), sebagaimana disajikan pada tabel 13.

Tabel 12. Jumlah Trip Rata-rata Harian AUP trayek ADL

\begin{tabular}{ccccccc}
\hline & Sabtu & Minggu & Senin & Selasa & Rabu & Kamis \\
\hline Jumlah Trip & 575 & 526 & 589 & 566 & 544 & 554 \\
Trip/kend & 4.87 & 4.46 & 4.99 & 4.80 & 4.61 & 4.69 \\
Rata-rata & \multicolumn{7}{c}{4.74} \\
\hline
\end{tabular}

Sumber : Hasil Perhitungan

Tabel 13. Jumlah Penumpang Rata-Rata AUP trayek ADL (Pnp/trip-kend)

\begin{tabular}{|c|c|c|c|c|c|c|c|c|c|c|c|c|}
\hline & \multicolumn{6}{|c|}{ Arjosari - Dinoyo - Landungsari } & \multicolumn{6}{|c|}{ Landungsari - Dinoyo - Arjosari } \\
\hline & Sabtu & Minggu & Senin & Selasa & Rabu & Kamis & Sabtu & Minggu & Senin & Selasa & Rabu & Kamis \\
\hline Maks & 19 & 18 & 18 & 18 & 18 & 18 & 18 & 18 & 17 & 19 & 16 & 18 \\
\hline Min & 7 & 7 & 7 & 7 & 7 & 9 & 7 & 7 & 7 & 7 & 8 & 6 \\
\hline $\begin{array}{c}\text { Rata- } \\
\text { rata }\end{array}$ & 12.19 & 11.81 & 11.56 & 12.00 & 12.50 & 12.31 & 11.13 & 10.81 & 10.75 & 12.06 & 11.44 & 9.94 \\
\hline Maks & \multicolumn{6}{|c|}{19} & \multicolumn{6}{|c|}{19} \\
\hline Min & \multicolumn{6}{|c|}{7} & \multicolumn{6}{|c|}{6} \\
\hline $\begin{array}{c}\text { Rata- } \\
\text { rata }\end{array}$ & \multicolumn{6}{|c|}{12.06} & \multicolumn{6}{|c|}{11.02} \\
\hline Maks & \multicolumn{12}{|c|}{19} \\
\hline Min & \multicolumn{12}{|c|}{6} \\
\hline $\begin{array}{c}\text { Rata- } \\
\text { rata }\end{array}$ & \multicolumn{12}{|c|}{11.64} \\
\hline
\end{tabular}

Berdasarkan penumpang rata-rata 11,64 penumpang/trip-kend dan trip hariannya sebesar 4,74 trip/hari, maka diestimasi produktivitas angkutan sebesar 55,17 penumpang/hari-kend atau $\quad 6.510$ penumpang/hari.

\section{Kebutuhan Angkutan}

Kapasitas penumpang AUP trayek ADL adalah 12 orang/kend, berdasarkan okupansi $70 \%$ diperoleh 8 penumpang/trip-kend dan trip berdasarkan waktu operasional 06.00 18.00 yaitu 7 trip/hari, maka diperoleh 56 penumpang/hari-kend. Prakiraan jumlah penumpang 6.510 penumpang/hari dan produktivitas kendaraan 56 pnp/hari-kend, maka diperoleh jumlah armada yang optimal yaitu 116 unit, sehingga perlu adanya pengurangan 2 unit armada.

\section{Pembahasan}

Load factor angkutan umum penumpang trayek ADL maksimum sebesar 158,33\% (19 penumpang) dan rata-rata kedua arah sebesar 97,06\% (11,64 penumpang). Diartikan bahwa tingkat keterisian dari angkutan umum penumpang trayek ADL lebih dari okupansi 70\% (Direktorat Jendral Perhubungan Darat). Berdasarkan pola naik turun penumpang diketahui penumpang maksimum di dalam kendaraan sebesar 15 penumpang, dimana jumlah penumpang lebih besar dari kapasitas AUP trayek ADL 12 orang. Kondisi ini menyebabkan pelayanan angkutan seperti kenyamanan menjadi rendah karena penumpang melebihi kapasitas angkutan. Sedangkan dengan penumpang rata-rata di dalam kendaraan berdasarkan pola naik turun sebesar 8,80 penumpang, dimana jumlah penumpang berkisar antara $8-9$ penumpang ini sesuai okupansi $70 \%$ yaitu 8 penumpang, yang artinya masih nyaman untuk penumpang.

Frekuensi angkutan umum penumpang trayek ADL rata-rata kedua arah sebesar 23,56 kend/jam dengan headway rata- 
rata sebesar 2,60 menit, ini berarti frekuensi dan headway angkutan umum penumpang trayek ADL masih dalam kondisi baik, artinya waktu tunggu penumpang kurang dari 3 menit terdapat AUP trayek ADL yang lewat.

Kecepatan tempuh angkutan umum penumpang trayek ADL rata-rata kedua arah sebesar $15,03 \mathrm{~km} / \mathrm{jam}$ atau dengan waktu tempuh 4,10 menit/km, ini berarti kecepatan tempuh angkutan umum penumpang trayek ADL masih dalam kondisi bisa di terima dengan jarak tempuh $\pm 14,5 \mathrm{~km}$. Waktu tempuh angkutan umum penumpang trayek ADL juga dipengaruhi oleh beberapa faktor eksternal diantaranya lalu-lintas dimana rute yang dilewati angkutan umum penumpang trayek ADL merupakan jalur utama yang melewati kawasan-kawasan kegiatan Kota Malang, terdapat beberapa simpang bersinyal, disamping kebiasaan supir berhenti waktu menunggu penumpang.

Jumlah armada 118 unit, produktivitas AUP trayek ADL sebesar 55,17 penumpang/hari-kend atau 6.510 penumpang/hari, diestimasi berdasarkan penumpang rata-rata $11,64 \mathrm{pnp} / \mathrm{hari}-\mathrm{kend}$ dan trip rata-rata 4,74 trip/hari-kend. Jumlah trip rata-rata 4,74 atau 5 trip/hari-kend dengan waktu tempuh \pm 1 jam dan waktu istirahat sekitar 2 jam dari jam operasional 06.0018.00, artinya bila jam kerja aktif AUP trayek ADL sekitar 7 jam, maka sekitar 5 jam angkutan tidak beroperasi, hal ini mengakibatkan banyak waktu yang terbuang, dengan demikian angkutan lebih banyak menghabiskan waktunya menunggu penumpang di terminal atau pinggir jalan.

Kapasitas penumpang AUP trayek ADL 12 orang/kend, berdasarkan okupansi 70\% (Direktorat Jendral Perhubungan Darat) yaitu 8 penumpang/trip-kend dan trip berdasarkan waktu operasional $06.00-18.00$ yaitu 7 trip/hari, diestimasikan produktivitas AUP trayek ADL sebesar 56 pnp/hari-kend. Penumpang rata-rata (eksisting) $6.510 \mathrm{pnp} / \mathrm{hari}$ dan produktivitas kendaraan 56 pnp/hari-kend, maka distimasikan jumlah armada yang optimal yaitu 116 unit armada dengan catatan $100 \%$ beroperasi, sehingga perlu adanya pengurangan 2 armada dari armada yang tersedia saat ini. Meningkatnya jumlah trip angkutan dari 4,74 trip/hari-kend menjadi 7 trip/hari-kend mengakibatkan biaya operasional kendaraan (BOK) menjadi lebih besar jika dibandingkan dengan produktivitas kendaraan sebelum dilakukan rekayasa sebesar 55,17 penumpang/hari-kend, penumpang ratarata $11,64 \mathrm{pnp} /$ trip-kend, trip rata-rata 4,74 trip/hari dan sesudah direkayasa sebesar 56 penumpang/hari-kend, penumpang (okupansi 70\%) 8 pnp/hari-kend dan trip angkutan sebesar 7 trip/hari-kend. Untuk meningkatkan produktivitas kendaraan, maka perlu adanya penambahan trip harian yang berdampak pada penyesuaian jumlah armada. Dengan jumlah armada yang beroperasi saat ini 118 unit masih layak untuk dioperasikan, adapun 2 unit armada tersebut dapat di rotasi dengan melakukan penjadwalan sehingga armada lainnya dapat beristirahat. Untuk dapat meningkatkan kinerja pelayanan angkutan maka perlu adanya penyesuaian jumlah armada dengan volume kebutuhan penumpang yang ada.

\section{KESIMPULAN}

- Kinerja angkutan umum penumpang trayek Arjosari - Dinoyo - Landungsari saat ini tahun 2015, load factor rata-rata $97,06 \%$, frekuensi rata-rata 23,56 $\mathrm{kend} / \mathrm{jam}$, headway waktu rata-rata 2,60 menit, waktu tempuh rata-rata 4,10 menit/km dan kecepatan tempuh rata-rata $15,03 \mathrm{~km} / \mathrm{jam}$.

- Produktivitas angkutan umum penumpang trayek Arjosari - Dinoyo - Landungsari saat ini tahun 2015, jumlah penumpang rata-rata sebesar 11,64 pnp/trip-kend, jumlah trip rata-rata sebesar 4,74 trip/hari dan produktivitas rata-rata $55 \mathrm{pnp} /$ harikend.

- Kebutuhan jumlah armada angkutan umum penumpang trayek Arjosari - Dinoyo Landungsari saat ini tahun 2015 yang optimal adalah 116 kendaraan.

\section{DAFTAR PUSTAKA}

Undang - undang No. 22 tahun 2009, Tentang Lalu Lintas dan Angkutan Jalan.

Peraturan Pemerintah Nomor 74 Tahun 2014 Tentang Angkutan Jalan.

Keputusan Direktorat Jenderal Perhubungan

Darat Nomor SK. 678/AJ. 206/DRJD/2002. Tentang Pedoman Teknis Penyelenggaraan Angkutan Umum 
Penumpang Umum Diwilayah Perkotaan Dalam Trayek Tetap dan Teratur.

Direktorat Jenderal Perhubungan Darat,(2002), Pedoman Teknis Penyelengaraan Angkutan Umum di Wilayah Perkotaan dalm Trayek Tetap dan Teratur.

Direktorat Jenderal Perhubungan Darat, (2002), Panduan Pengumpulan Data Angkutan Umum Perkotaan.

Direktorat Jenderal Perhubungan Darat,(1996), Pedoman Teknis Penyelenggaraan Angkutan Penumpang Umum di Wilayah Perkotaan dalam Trayek Tetap dan Teratur.

Direktorat Jenderal Perhubungan Darat, (1995), Menuju Lalu Lintas dan Angkutan Jalan Yang Tertip.

Armin. H.Y. (2014), Evaluasi Kinerja Angutan Umum Penumpang Kota Mataram (Studi Kasus : Rute Sweta Ampenan). Skripsi Teknik Sipil, Fakultas Teknik, UMM. Malang.

Asikin, Muslich Zainal.2001. Sistem Manajemen Transportasi Kota. Yogyakarta : Penerbit UGM.

Marsudi, Ismiyati dan Y,I. Wicaksono. (2006), Analisis Kinerja Mobil Penumpang Umum (MPU) dan Sistem Jaringan Trayek Di Kota Salatiga, Pilar Volume 15 No 2, September 2006, Magister Teknik Sipil Universitas Diponegoro. Semarang. Morlok, E.K,(1978), Pengantar Teknik dan Perencanaan Transportasi, Terjemahan oleh Johan Kelanaputra Hainim 1985. Penerbit Erlangga, Jakarta.

Nasution, H.M.N., (2008), Manajemen Transportasi, Ghalia Indonesia, Jakarta.

Tamin, O.Z, (1997), Perencanaan dan Permodelan Transportasi, penerbit ITB, Bandung.

Warpani, Suwardjoko. (2002), Pengolahan Lalu Lintas dan Angkutan Jalan, Penerbit ITB, Bandung 